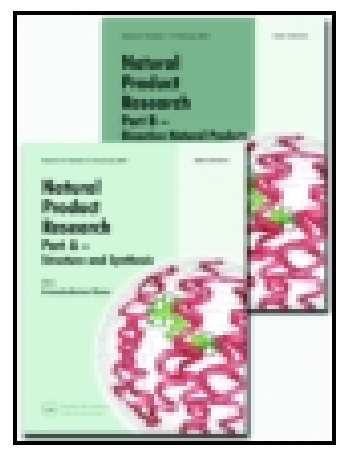

Natural Product Research

Formerly Natural Product Letters

ISSN: 1478-6419 (Print) 1478-6427 (Online) Journal homepage: https://www.tandfonline.com/loi/gnpl20

\title{
Calotetrapterins A-C, three new pyranoxanthones and their cytotoxicity from the stem bark of Calophyllum tetrapterum Miq
}

\author{
Mulyadi Tanjung, Tjitjik Srie Tjahjandarie, Ratih Dewi Saputri, Baharrani Dwi \\ Kurnia, Muhammad Faisal Rachman \& Yana Maolana Syah
}

To cite this article: Mulyadi Tanjung, Tjitjik Srie Tjahjandarie, Ratih Dewi Saputri, Baharrani Dwi Kurnia, Muhammad Faisal Rachman \& Yana Maolana Syah (2019): Calotetrapterins A-C, three new pyranoxanthones and their cytotoxicity from the stem bark of Calophyllum tetrapterum Miq, Natural Product Research

To link to this article: https://doi.org/10.1080/14786419.2019.1634714

View supplementary material 저

Published online: 15 Jul 2019.

Submit your article to this journal 주

View Crossmark data 


\title{
Calotetrapterins $A-C$, three new pyranoxanthones and their cytotoxicity from the stem bark of Calophyllum tetrapterum Miq
}

\author{
Mulyadi Tanjung ${ }^{a}$, Tjitjik Srie Tjahjandarie ${ }^{a}$, Ratih Dewi Saputri ${ }^{a}$, Baharrani Dwi \\ Kurnia $^{\mathrm{a}}$, Muhammad Faisal Rachman ${ }^{\mathrm{a}}$ and Yana Maolana Syah ${ }^{\mathrm{b}}$ \\ ${ }^{a}$ Natural Products Chemistry Research Group, Organic Chemistry Division, Department of Chemistry, \\ Faculty of Science and Technology, Universitas Airlangga, Surabaya, Indonesia; ${ }^{b}$ Natural Products \\ Chemistry Research Group, Organic Chemistry Division, Bandung Institute of Technology, \\ Bandung, Indonesia
}

\section{ABSTRACT}

Three new pyranoxanthones, calotetrapterins A-C (1-3) were isolated from the stem bark of Calophyllum tetrapterum Miq along with three known xanthones, $\alpha$-mangostin (4), garciniafuran (5), and pyranojacareubin (6). All structures were elucidated based on their IR, UV, HRESIMS, $1 \mathrm{D}\left({ }^{1} \mathrm{H},{ }^{13} \mathrm{C}\right)$ and $2 \mathrm{D}$ (HMBC, HMQC) NMR spectral data. Compounds 1-6 were tested to P-388 cells for cytotoxic activity, compound 2 exhibited high activity with $\mathrm{IC}_{50}$ value $1.0 \mu \mathrm{M}$.
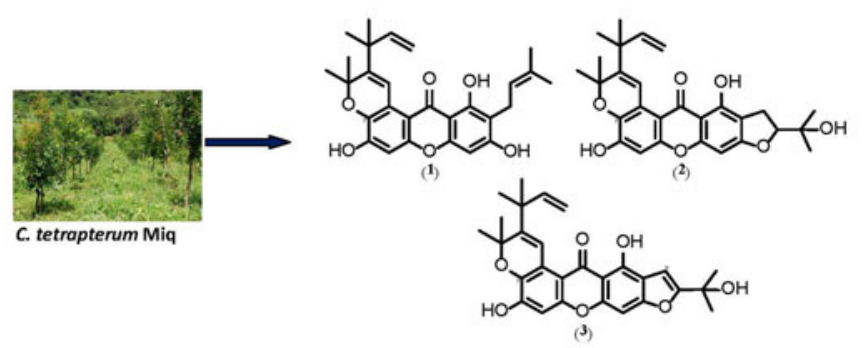

\section{ARTICLE HISTORY}

Received 9 April 2019

Accepted 18 June 2019

\section{KEYWORDS}

Calotetrapterins A-C; pyranoxanthone;

Calophyllum tetrapterum;

P-388 cell

\section{Introduction}

The genus Calophyllum (Calophyllaceae) comprises about 198 species found mainly in the restrictive area of Southeast Asia. Calophyllum plants are source of phenolic compounds especially xanthones (Ferchichi et al. 2012; Daud et al. 2016), benzofurans (Tanjung et al. 2018) and 4-phenylcoumarins (Zhong et al. 2010) containing isoprenyl as side chain. Isoprenylation of phenolic compounds displays as a major chromophore to increase their cytotoxicity activities against various human cancer cells (Mah et al.

CONTACT Mulyadi Tanjung mulyadi-t@fst.unair.ac.id

(1) Supplemental data for this article can be accessed at https://doi.org/10.1080/14786419.2019.1634714.

(C) 2019 Informa UK Limited, trading as Taylor \& Francis Group 
2015). Calophyllum tetrapterum Miq. is one species plant found originated in East Kalimantan, Indonesia. Based on our knowledge, no pyranoxanthones from C.tetrapterum has been reported. As part of the phytochemical investigation on Calophyllum in Indonesia, six pyranoxanthones including three new pyranoxanthones (1-3) were isolated from the stem bark of $C$. tetrapterum. The cytotoxic activity of pyranoxanthones against murine leukemia P-388 is also reported.

\section{Result and discussion}

Calotetrapterin A (1) showed absorption bands at $\lambda_{\max } 247,264,322 \mathrm{~nm}$ consimilar with a xanthone chromophore (Tanjung et al. 2018). The HRESIMS spectrum displayed negative ion peak [M-H] $]^{-}$at $\mathrm{m} / \mathrm{z} 461.1971$ appropriate with a molecular formula of $\mathrm{C}_{28} \mathrm{H}_{30} \mathrm{O}_{6}$. The IR spectrum of 1 showed strong absorption for hydroxyl $\left(3423 \mathrm{~cm}^{-1}\right)$, conjugated carbonyl $\left(1622 \mathrm{~cm}^{-1}\right)$, and aromatic $\left(1577\right.$ and $1460 \mathrm{~cm}^{-1}$ ) groups. The ${ }^{1} \mathrm{H}$ NMR spectrum of 1 demonstrated two aromatic signals at $\delta_{\mathrm{H}} 6.40(\mathrm{H}-4)$ and $6.77(\mathrm{H}-5)$ recommended for a 1,2,3,6,7,8-hexasubstituted xanthone (Azebaze et al. 2004). Additionally, the ${ }^{1} \mathrm{H}$ NMR spectrum of 1 also showed the signals of hydroxyl group, 3methyl-2-butenyl (isoprenyl), 3-methyl-1-butenyl, and a monosubstituted 2,2-dimethylpyrano ring confirmed by $\mathrm{HMBC}$ spectrum. A signal at $\delta_{\mathrm{H}} 13.77$ is the signal a hydroxyl group at $\mathrm{C}-1$ of xanthone structure. The presence of 3-methyl-2-butenyl side chain signals showed a methylene signal at $\delta_{\mathrm{H}} 3.34(2 \mathrm{H}, \mathrm{d}, J=7.3 \mathrm{~Hz}, \mathrm{H}-1)$, a vinylic at $\delta_{\mathrm{H}} 5.27$ $(1 \mathrm{H}, \mathrm{tm}, J=7.3 \mathrm{~Hz}, \mathrm{H}-2)$, and two methyls at $\delta_{\mathrm{H}} 1.63(3 \mathrm{H}, \mathrm{s}, \mathrm{H}-4)$, and $1.77(3 \mathrm{H}, \mathrm{s}, \mathrm{H}-5)$. The signal of a monosubstituted 2,2-dimethylpyrano ring demonstrated a vinylic at $\delta_{\mathrm{H}}$ $8.19(1 \mathrm{H}, \mathrm{s}, \mathrm{H}-4)$, and a gem dimethyl at $1.49(6 \mathrm{H}, \mathrm{s}, \mathrm{H}-5 / \mathrm{H}-6)$. A downfield signal at $\delta_{\mathrm{H}}$ 8.19 indicating for a vinylic from influenced by anisotropic factor from carbonyl group (Azebaze et al. 2004). Furthermore, the signal of 3-methyl-1-butenyl side chain showed a vinylic at $\delta_{\mathrm{H}} 6.02(1 \mathrm{H}, \mathrm{dd}, J=10.6 ; 17.5 \mathrm{~Hz}, \mathrm{H}-8)$, a methylene terminal $\left[\delta_{\mathrm{H}} 5.16(1 \mathrm{H}\right.$, $\mathrm{dd}, J=1.1 ; 17.5 \mathrm{~Hz}, \mathrm{H}-9$ á) and $\left.\delta_{\mathrm{H}} 5.08(1 \mathrm{H}, \mathrm{dd}, J=1.1 ; 10.6 \mathrm{~Hz}, \mathrm{H}-9 \mathrm{~b})\right]$, and a gem dimethyl at $\delta_{\mathrm{H}} 1.41(6 \mathrm{H}, \mathrm{s}, \mathrm{H}-10 / \mathrm{H}-11)$. The ${ }^{13} \mathrm{C}$ NMR spectrum (APT experiment) of 1 demonstrated the existence of six methyl carbons, two methylene carbons, five methine carbons and 15 quaternary carbons (including one carbonyl carbon and six oxyaryl carbons). The location of hydroxyl, 3-methyl-2-butenyl side chain, 3-methyl-1butenyl side chain, and a monosubstituted 2,2-dimethylpyrano ring was confirmed with HMQC and HMBC spectra. The signal of a chelated hydroxyl at $\delta_{\mathrm{H}} 13.77(1-\mathrm{OH})$ showed correlation to $C-1\left(\delta_{C} 161.5\right), C-2\left(\delta_{C} 110.9\right), C-9 a\left(\delta_{C} 103.8\right)$ and methylene signal of 3-methyl-2-butenyl side chain at $\mathrm{H}-1^{\prime}\left(\delta_{\mathrm{H}} 3.34\right)$ correlated to $\mathrm{C}-2\left(\delta_{\mathrm{C}} 110.9\right), \mathrm{C}-3$ $\left(\delta_{\mathrm{C}}\right.$ 162.9), $\mathrm{C}-2^{\prime}\left(\delta_{\mathrm{C}} 123.4\right), \mathrm{C}-3^{\prime}\left(\delta_{\mathrm{C}} 131.4\right)$ showing that isoprenyl side chain located at $\mathrm{C}-2$. The signal aromatic at $\delta_{\mathrm{H}} 6.40(\mathrm{H}-4)$ showed correlation with to $\mathrm{C}-2\left(\delta_{\mathrm{C}} 110.9\right), \mathrm{C}-3$ $\left(\delta_{\mathrm{C}}\right.$ 162.9), C-4a $\left(\delta_{\mathrm{C}} 155.9\right)$, and $\mathrm{C}-9 \mathrm{a}\left(\delta_{\mathrm{C}} 103.8\right)$ supported that an isoprenyl at C-2. Furthermore, the signal at $\delta_{\mathrm{H}} 6.77(\mathrm{H}-5)$ correlated to three oxyarils [C- $6\left(\delta_{\mathrm{C}} 154.1\right), \mathrm{C}-7$ $\left.\left(\delta_{C} 137.6\right)\right], C-10 a\left(\delta_{C} 153.3\right)$, and a quaternary carbon at C-8a $\left(\delta_{C} 108.4\right)$. Consequently, a monosubstituted 2,2-dimethylpyrano ring attached to aromatic at C-7 and C-8. The location of a monosubstituted 2,2-dimethylpyrano ring attached to C-7 and C-8 was supported by the long-range correlations of the proton signal at $\delta_{\mathrm{H}} 8.19(\mathrm{H}-4)$ to $\mathrm{C}-7$ $\left(\delta_{C}\right.$ 137.6), C-8a $\left(\delta_{C} 108.4\right), C-2^{\prime}\left(\delta_{C}\right.$ 80.3), C-7' $\left(\delta_{C}\right.$ 42.7) unequivocally located the 
3-methyl-1-butenyl side chain at $\mathrm{C}-3$. The existence of long-range correlations of a gem dimethyl at $\delta_{\mathrm{H}} 1.41\left(\mathrm{H}-10^{\prime} / \mathrm{H}-11\right)$ to $\mathrm{C}-3^{\prime}\left(\delta_{\mathrm{C}} 149.7\right), \mathrm{C}-7^{\prime}\left(\delta_{\mathrm{C}} 42.7\right), \mathrm{C}-8^{\prime}\left(\delta_{\mathrm{C}} 147.9\right), \mathrm{C}-$ $11^{\prime} / \mathrm{C}-10^{\prime}\left(\delta_{\mathrm{C}} 42.7\right)$ and the signal of a methylene terminal at $\delta_{\mathrm{H}} 5.16$, and $\delta_{\mathrm{H}} 5.08(\mathrm{H}-9)$ correlated to $C-7^{\prime}\left(\delta_{C} 42.7\right), C-8^{\prime}\left(\delta_{C} 147.9\right)$ obviously placed the 3-methyl-1-butenyl side chain at C-3. Based on the above-mentioned spectral orientation, the structure of calotetrapterin A was established as $\mathbf{1 .}$

Calotetrapterin B (2) was obtainted also as a yellow solid, showed UV ( $\lambda_{\max } 245$, $268,320)$, and IR $\left(3330,1616,1571,1463 \mathrm{~cm}^{-1}\right)$ absorptions very resemblant with 1 . Its molecular formula was established as $\mathrm{C}_{28} \mathrm{H}_{30} \mathrm{O}_{7}$ showed $[\mathrm{M}+\mathrm{H}]^{+}$ion at $\mathrm{m} / \mathrm{z} 479.2076$ by the HRESIMS. The NMR spectrum $\left({ }^{1} \mathrm{H}\right.$ and $\left.{ }^{13} \mathrm{C}\right)$ of $\mathbf{2}$ had very consimilar with $\mathbf{1}$. The major difference, the ${ }^{1} \mathrm{H}$ and ${ }^{13} \mathrm{C}$ NMR of 2 showed a 2-(1-hydroxy-1-methylethyl)dihydrofuran ring attached to C-2 and C-3. The location of a 2-(1-hydroxy-1-methylethyl)dihydrofuran ring was assigned by $\mathrm{HMBC}$ and $\mathrm{HMQC}$ spectrum. The long-range correlations a chelated hydroxyl group at $\delta_{\mathrm{H}} 13.67(1-\mathrm{OH})$ to $\mathrm{C}-1\left(\delta_{\mathrm{C}} 158.7\right), \mathrm{C}-2\left(\delta_{\mathrm{C}}\right.$ 108.8), C-9a $\left(\delta_{\mathrm{C}} 103.8\right)$, and the signal of a methylene of dihydrofuran ring at $\delta_{\mathrm{H}} 3.15$ $(\mathrm{H}-3)$ correlated to $\mathrm{C}-2\left(\delta_{\mathrm{C}} 108.8\right), \mathrm{C}-4^{\prime}\left(\delta_{\mathrm{C}} 71.4\right)$ showed that a 2-(1-hydroxy-1-methylethyl)dihydrofuran ring attached to $\mathrm{C}-2$ and $\mathrm{C}-3$. The signal of oxymethine at $\delta_{\mathrm{H}} 4.82$ $(\mathrm{H}-2)$ correlated to $\mathrm{C}-5^{\prime}\left(\delta_{\mathrm{C}} 25.9\right), \mathrm{C}-6^{\prime}\left(\delta_{\mathrm{C}} 25.6\right)$ supporting that the location of a $2-(1-$ hydroxy-1-methylethyl)dihydrofuran fused at C-2 and C-3. Other HMBC correlations of 2 consistent with structure of calotetrapterin B.

Calotetrapterin $\mathrm{C}$ (3) was obtained also as a yellow solid. Its molecular formula was established as $\mathrm{C}_{28} \mathrm{H}_{28} \mathrm{O}_{7}$ with HRESIMS spectra by means of ion peak $[\mathrm{M}+\mathrm{H}]^{+}$at $\mathrm{m} / \mathrm{z}$ 477.1911. The NMR $\left({ }^{1} \mathrm{H}\right.$ and $\left.{ }^{13} \mathrm{C}\right)$ spectra data of $\mathbf{3}$ were identically to those $\mathbf{2}$. The main difference, in the NMR $\left({ }^{1} \mathrm{H},{ }^{13} \mathrm{C}\right)$ of $\mathbf{3}$ displayed a 2-(1-hydroxy-1-methylethyl)furan ring and dertemined based on $\mathrm{HMBC}$ and $\mathrm{HMQC}$ measurement. The $\mathrm{HMBC}$ long-range correlations of a chelated hydroxyl at 1-OH $\left(\delta_{\mathrm{H}} 14.25\right)$ exhibited that cross peaks with $\mathrm{C}-1\left(\delta_{\mathrm{C}}\right.$ 156.8), $\mathrm{C}-2\left(\delta_{\mathrm{C}} 113.7\right)$, and $\mathrm{C}-9 \mathrm{a}\left(\delta_{\mathrm{C}} 105.6\right)$. The signal of a vinylic of furan ring at $\mathrm{H}-3^{\prime}\left(\delta_{\mathrm{H}}\right.$ 6.86) correlated to $\mathrm{C}-2\left(\delta_{\mathrm{C}} 113.7\right), \mathrm{C}-3\left(\delta_{\mathrm{C}} 160.0\right), \mathrm{C}-2^{\prime}\left(\delta_{\mathrm{C}} 165.6\right)$ and a gem dimethyl at $\mathrm{H}-$ $5^{\prime} / \mathrm{H}-6^{\prime}\left(\delta_{\mathrm{H}} 1.62\right)$ showing correlations with $\mathrm{C}-2^{\prime}\left(\delta_{\mathrm{C}} 165.6\right), \mathrm{C}-4^{\prime}\left(\delta_{\mathrm{C}} 67.9\right)$. The long-range correlations of $\delta_{H} 6.86$ and $\delta_{H} 1.62$ with carbon signals were supported the location of a 2-(1-hydroxy-1-methylethyl)furan ring fused at C-2 and C-3 on xanthone skeleton. Based on the above NMR data, structure $\mathbf{3}$ was established as calotetrapterin C.

Three known xanthones, $\alpha$-mangostin (4), garciniafuran (5), pyranojacareubin (6) by $1 \mathrm{D}\left({ }^{1} \mathrm{H},{ }^{13} \mathrm{C}\right)$ and $2 \mathrm{D}$ (HMQC, HMBC) NMR, HRESIMS data very resemblant with published data (Chae et al. 2012, Shiozaki et al. 2013).

The cytotoxic activity of compounds (1-6) were evaluated for their cytotoxicity using cell viability in murine leukemia P-388 with MTT method. These compounds displayed $I_{50}$ values of $5.4 \pm 0.6,1.0 \pm 0.2,4.1 \pm 0.4,212.0 \pm 1.1,93.5 \pm 1.3$, and $71.2 \pm 1.2 \mu \mathrm{M}$, respectively. Those cytotoxic data suggested that all of new compounds (1-3) showed high activity and known compounds (4-6) were inactive. Influence of a pyrano ring fused at C-7 and C-8 along with a 3-methyl-1-butenyl side chain attached at C-3" suggested as a key factor to enhance cytotoxic effect (Ito et al. 2002). Hence, the lipophilicity of a 3-methyl-1-butenyl side chain on pyrano ring contributes to damage the cell membranes of P-388 cells. The main difference between the three new compounds (1-3) be located in the substituent at C-2 and C-3. The existence of a 
dihydrofuran ring of compound $\mathbf{2}$ tend to be more active than a furan ring of compound $\mathbf{3}$ fused at C-2 and C-3. However, influence of a furan ring of compound $\mathbf{3}$ slighly more active than the existence of the isoprenyl side chain at C-2 and hydroxyl group at $\mathrm{C}-3$ of compound $\mathbf{1}$.

\section{Experimental}

\subsection{Plant material}

The fresh stem barks of C. tetrapterum were collected from Mendawak River, East Kalimantan, Indonesia in Apr 2016. The plant was authenticated by Mr. Ismail Rachman, botanist from the Herbarium Bogoriense, LIPI, Bogor. A specimen (CT 65798) was deposited as a reference.

\subsection{Extraction and isolation}

The dried stem barks of C. tetrapterum $(1.8 \mathrm{~kg})$ was extracted successively at room temperature with $\mathrm{MeOH}$ over a period of two days, and then evaporation of the solvent under reduced pressure gave a dark brown residue $(125 \mathrm{~g})$. The extract was redissolved in $\mathrm{MeOH}-\mathrm{H}_{2} \mathrm{O}$ (9:1) and partitioned with $n$-hexane $(32 \mathrm{~g})$ and EtOAc (26 g) fractions. A part of EtOAc fraction $(25 \mathrm{~g}$ ) was subjected to VLC chromatography over silica gel and eluted with $n$-hexane-EtOAc (from 9:1 to 1:1) to give three fractions A-C. TLC analysis of fraction A $(2.5 \mathrm{~g})$ showed no phenolic compounds with UV light, therefore analysis was not continued. Fraction B $(3.6 \mathrm{~g})$ was fractionated with CC chromatography, eluted with $n$-hexane-EtOAc (from 19:1 to 7:3) gave two subfractions $B_{1}-B_{2}$. Subfraction $B_{1}(325 \mathrm{mg})$ was purified by planar radial chromatography using $n$-hexane$\mathrm{CHCl}_{3}$ (from 4:1 to $1: 1$ ) to yielded compound 5 (10 mg) and compound 6 (15 mg). Subfraction $B_{2}(410 \mathrm{mg})$ was purified by planar radial chromatography using $n$-hexaneacetone (from 19:1 to 4:1) to obtain compound 2 (13 mg) and compound 3 (18 mg). Fraction C (4.5 g) was separated by CC chromatography and eluted with $n$-hexaneEtOAC (from $4: 1$ to $1: 1$ ) to produce three subfractions $C_{1}-C_{3}$. Subfraction $C_{3}$ was purified by planar radial chromatography using $n$-hexane-EtOAc (from 9:1 to 3:7) to yielded compound 1 (8 mg) and compound 4 (9 mg).

\subsection{Spectral data}

Calotetrapterin A (1): yellow solid, UV/Vis (MeOH) $\lambda_{\max }(\mathrm{nm})$ (log $\left.\varepsilon\right): 247$ (4.64), 264 (4.60), and 322 (4.38). IR (KBr) $\vee\left(\mathrm{cm}^{-1}\right)$ : 3423, 2972, 2923, 2852, 1622, 1577, 1460 and 1188. ${ }^{1} \mathrm{H}-\mathrm{NMR}\left(400 \mathrm{MHz}\right.$, acetone- $\left.d_{6}\right) \delta_{\mathrm{H}} \mathrm{ppm}$ : $13.77(1 \mathrm{H}, s, 1-\mathrm{OH}), 6.40(1 \mathrm{H}, s, \mathrm{H}-4), 6.77$ $(1 \mathrm{H}, s, \mathrm{H}-5), 3.34(2 \mathrm{H}, d, J=7.3 \mathrm{~Hz}, \mathrm{H}-1), 5.27(1 \mathrm{H}, t m, J=7.3 \mathrm{~Hz}, \mathrm{H}-2), 1.63(3 \mathrm{H}, \mathrm{s}, \mathrm{H}-4)$, $1.77(3 \mathrm{H}, \mathrm{s}, \mathrm{H}-5), 8.19(1 \mathrm{H}, \mathrm{s}, \mathrm{H}-4), 1.49(6 \mathrm{H}, \mathrm{s}, \mathrm{H}-5 / \mathrm{H}-6), 6.02(1 \mathrm{H}, d d, J=10.6 ; 17.5 \mathrm{~Hz}$, $\mathrm{H}-8), 5.16(1 \mathrm{H}, d d, J=1.1 ; 17.5 \mathrm{~Hz}, \mathrm{H}-9 a ́), 5.08(1 \mathrm{H}, d d, J=1.1 ; 10.6 \mathrm{~Hz}, \mathrm{H}-9 \mathrm{~b}), 1.41(6 \mathrm{H}$, s, H-10/H-11). ${ }^{13} \mathrm{C}-\mathrm{NMR}\left(100 \mathrm{MHz}\right.$, acetone- $\left.d_{6}\right), \delta_{\mathrm{C}}$ ppm: $161.5(\mathrm{C}-1), 110.9(\mathrm{C}-2), 162.9$ (C-3), 93.2 (C-4), 155.9 (C-4a), 102.9 (C-5), 154.1 (C-6), 137.6 (C-7), 122.8 (C-8), 108.4 (C8a), 183.1 (C-9), 103.8 (C-9a), 153.3 (C-10a), 21.9 (C-1), 123.4 (C-2), 131.4 (C-3), 25.9 (C4), 17.8 (C-5), 80.3 (C-2), 149.7 (C-3), 118.8 (C-4), 27.3 (C-5/C-6), 42.7 (C-7), 147.9 (C-8), 
112.2 (C-9), 28.6 (C-10/C-11). HRESIMS: $\mathrm{m} / \mathrm{z}$ [M-H] $]^{-}$calcd. for $\mathrm{C}_{28} \mathrm{H}_{30} \mathrm{O}_{6}$ 461.1964, found 461.1971.

Calotetrapterin B (2): yellow solid, UV/Vis (MeOH) $\lambda_{\max }(\mathrm{nm})$ (log $\left.\varepsilon\right): 245$ (4.62), 268 (4.59), and 320 (4.36). IR (KBr) $\vee\left(\mathrm{cm}^{-1}\right)$ : 3330, 2958, 2952, 2856, 1616, 1571, 1463 and 1172. ${ }^{1} \mathrm{H}-\mathrm{NMR}\left(400 \mathrm{MHz}\right.$, acetone- $\left.d_{6}\right) \delta_{\mathrm{H}} \mathrm{ppm}: 13.67(1 \mathrm{H}, \mathrm{s}, 1-\mathrm{OH}), 6.29(1 \mathrm{H}, \mathrm{s}, \mathrm{H}-4), 6.80$ $(1 \mathrm{H}, s, \mathrm{H}-5), 4.82(1 \mathrm{H}, d, J=7.9 ; 9.4 \mathrm{~Hz}, \mathrm{H}-2), 3.15(2 \mathrm{H}, t, J=8.2 \mathrm{~Hz}, \mathrm{H}-3), 1.24(3 \mathrm{H}, s, \mathrm{H}-$ 5), $1.29(3 \mathrm{H}, s, \mathrm{H}-6), 8.18(1 \mathrm{H}, \mathrm{s}, \mathrm{H}-4), 1.50(6 \mathrm{H}, s, \mathrm{H}-5 / \mathrm{H}-6), 6.03(1 \mathrm{H}, d d, J=10.6$; $17.5 \mathrm{~Hz}, \mathrm{H}-8), 5.16(1 \mathrm{H}, d d, J=1.1 ; 17.5 \mathrm{~Hz}, \mathrm{H}-9 a ́), 5.08(1 \mathrm{H}, d d, J=1.1 ; 10.6 \mathrm{~Hz}, \mathrm{H}-9 \mathrm{~b})$, $1.41(6 \mathrm{H}, s, \mathrm{H}-10 / \mathrm{H}-11) .{ }^{13} \mathrm{C}-\mathrm{NMR}\left(100 \mathrm{MHz}\right.$, acetone- $\left.d_{6}\right), \delta_{\mathrm{C}} \mathrm{ppm}: 158.7(\mathrm{C}-1), 108.8(\mathrm{C}-$ 2), 167.8 (C-3), 88.7 (C-4), 158.1 (C-4a), 102.9 (C-5), 153.4 (C-6), 137.8 (C-7), 122.7 (C-8), 108.3 (C-8a), 183.3 (C-9), 103.8 (C-9a), 154.6 (C-10a), 92.8 (C-2), 27.0 (C-3), 71.4 (C-4), 25.9 (C-5), 25.6 (C-6), 80.4 (C-2), 149.8 (C-3), 118.7 (C-4), 27.3 (C-5'C-6), 42.7 (C-7), 147.8 (C-8), $112.3(\mathrm{C}-9), 28.7$ (C-10/C-11). HRESIMS: $\mathrm{m} / \mathrm{z}[\mathrm{M}+\mathrm{H}]^{+}$calcd. for $\mathrm{C}_{28} \mathrm{H}_{30} \mathrm{O}_{7}$ 479.2070, found 479.2076 .

Calotetrapterin C (3): yellow solid, IR (KBr) $\vee\left(\mathrm{cm}^{-1}\right)$ : 3450, 2958, 2927, 2858, 1620, 1573, 1461 and 1172. ${ }^{1} \mathrm{H}-\mathrm{NMR}\left(400 \mathrm{MHz}\right.$, acetone- $\left.d_{6}\right) \delta_{\mathrm{H}} \mathrm{ppm:} 14.25(1 \mathrm{H}, \mathrm{s}, 1-\mathrm{OH}), 7.05$ $(1 \mathrm{H}, s, \mathrm{H}-4), 6.78(1 \mathrm{H}, \mathrm{s}, \mathrm{H}-5), 6.86(1 \mathrm{H}, \mathrm{s}, \mathrm{H}-3), 1.62(6 \mathrm{H}, \mathrm{s}, \mathrm{H}-5 / \mathrm{H}-6), 8.19(1 \mathrm{H}, \mathrm{s}, \mathrm{H}-4)$, $1.52(6 \mathrm{H}, s, \mathrm{H}-5 / \mathrm{H}-6), 6.04(1 \mathrm{H}, d d, J=10.6 ; 17.6 \mathrm{~Hz}, \mathrm{H}-8), 5.18(1 \mathrm{H}, d d, J=1.1 ; 17.6 \mathrm{~Hz}$, $\mathrm{H}-9 a ́), 5.10(1 \mathrm{H}, d d, J=1.1 ; 10.6 \mathrm{~Hz}, \mathrm{H}-9 \mathrm{~b}), 1.43(6 \mathrm{H}, \mathrm{s}, \mathrm{H}-10 / \mathrm{H}-11) .{ }^{13} \mathrm{C}-\mathrm{NMR}(100 \mathrm{MHz}$, acetone- $\left.d_{6}\right), \delta_{\mathrm{C}}$ ppm: 156.8 (C-1), 113.7 (C-2), 160.0 (C-3), 90.2 (C-4), 154.1 (C-4a), 102.9 (C-5), 152.8 (C-6), 137.8 (C-7), 122.0 (C-8), 108.1 (C-8a), 182.2 (C-9), 105.6 (C-9a), 154.9 (C-10a), 165.6 (C-2), 98.1 (C-3), 67.9 (C-4), 29.2 (C-5/C-6), 80.4 (C-2), 149.8 (C-3), 118.7 (C-4), 27.3 (C-5/C-6), 42.5 (C-7), 147.9 (C-8), 112.3 (C-9), 28.7 (C-10'/C-11). HRESIMS: m/z $[\mathrm{M}+\mathrm{H}]^{+}$calcd. for $\mathrm{C}_{28} \mathrm{H}_{28} \mathrm{O}_{7} 477.1913$, found 477.1911 .

\subsection{Cytotoxic assay}

All of compounds (1-6) were assayed cytotoxic activity against murine leukemia P-388 cell in accordance with the MTT colorimetric method as erenow described (Tanjung et al. 2018; Saputri et al. 2018).

\section{Conclusions}

In summary, three new pyranoxanthones, calotetrapterins A-C (1-3) were isolated from the stem bark of $C$. tetrapterum Miq together with three known xanthones, $\alpha$-mangostin (4), garciniafuran (5) and pyranojacareubin (6). Compound 2 showed high activity against murine leukemia P-388.

\section{Disclosure statement}

The authors proclaim no potential conflict of interest.

\section{Funding}

This work was supported by Universitas Airlangga, Surabaya, Indonesia through Hibah Riset Mandat grant 2018 number 1918/UN3.1.8./LT/2018. 


\section{References}

Azebaze AGB, Meyer M, Bodo B, Nkengfack AE. 2004. Allanxanthone B, a polyisoprenylated xanthone from the stem bark of Allanblackia monticola Staner L.C. Phytochem. 65(18):2561-2564.

Chae H-S, Oh S-R, Lee H-K, Joo SH, Chin Y-W. 2012. Mangosteen xanthones, $\alpha$ and $\gamma$-mangostins, inhibit allergic mediators in bone marrow-derived mast cell. Food Chem. 134(1):397-400.

Daud SB, Ee GCL, Malek EA, Ahmad Z, Hashim NM, See I, Teh SS, Ismail A. 2016. A new pyranoxanthone from the stem bark of Calophyllum buxifolium. Chem Nat Compd. 52:807-809.

Ferchichi L, Derbre S, Mahmood K, Toure K, Guilet D, Litaudon M, Awang K, Hadi AHA, Ray AML, Richomme P. 2012. Bioguided fractionation and isolation of natural inhibitors advanced glycation end-products (AGEs) from Calophyllum flavoramulum. Phytochem. 78:98-106.

Ito C, Itoigawa M, Mishina Y, Filho VC, Mukainaka T, Tokuda H, Nishino H, Furukawa H. 2002. Chemical constituents of Calophyllum brasiliensis: structure elucidation of seven new xanthones and their cancer chemopreventive activity. J. Nat Prod. 65(3):267-272.

Mah SH, Ee GCL, Teh SS, Sukari MA. 2015. Calophyllum inophyllum and Calophyllum soulattri source of anti-proliferative xanthones and their structure-activity relationships. Nat Prod Res. 29(1):98-101.

Saputri RD, Tjahjandarie TS, Tanjung M. 2018. Meliglabrin, a new flavonol derivative from the leaves of Melicope glabra (Blume) T.G. Hartley. Nat Prod Sci. 24(3):155-158.

Shiozaki T, Fukai M, Hermawati E, Juliawaty LD, Syah YM, Hakim EH, Puthongking P, Suzuki T, Kinoshita K, Takahashi K, Koyama K. 2013. Anti-angiogenic effect of $\alpha$-mangostin. J Nat Med. 67(1):202-206.

Tanjung M, Rachmadiarti F, Prameswari A, Agyani VUW, Saputri RD, Tjahjandarie TS, Syah YM. 2018. Airlanggins $A-B$, two new isoprenylated benzofuran-3-ones from the stem bark of Calophyllum soulattri. Nat Prod Res. 32(13):1493-1498.

Tanjung M, Rachmadiarti F, Saputri RD, Tjahjandarie TS. 2018. Mesucalophylloidin, a new isoprenylated 4-phenylcoumarin from Mesua calophylloides (Ridl.) Kosterm . Nat Prod Res. 32(9): 1062-1067.

Zhong H, Ruan J-L, Yao Q-Q. 2010. Two new 4-arylcoumarins from the seeds of Calophyllum polyanthum. J Asian Nat Prod Res. 12(7):562-568. [InsertedFromOnline[pubmedMismatch]] 